\title{
Gathering "Mouse Roots," Among the Naukan and Chukchi of the Russian Far East
}

\author{
Kevin Jernigan ${ }^{1 *}$, Olga Belichenko ${ }^{2}$, Valeria Kolosova ${ }^{2}$, Darlene Orr $^{3}$, and Maria Pupynina ${ }^{4}$ \\ ${ }^{1}$ Cross-cultural Studies Program, University of Alaska, Fairbanks, USA. ${ }^{2}$ Department of Environmental Sciences, Informatics \\ and Statistics, Università Ca' Foscari, Venice, Italy. ${ }^{3}$ Ethnobotany Program, University of Alaska, Fairbanks, USA. ${ }^{4}$ Department \\ of Languages of Russia, Institute for Linguistic Studies, St. Petursburg, Russia. \\ *kjernigan@alaska.edu
}

\begin{abstract}
The authors worked from 2014-2016, with 67 Naukan and Chukchi participants in six villages on the subject of "mouse roots," a category of edible plants, including tubers of five species, taken from caches of Microtus voles. Only eight out of 44 Chukchi and none of the Naukan respondents said that they still actively gather these foods. However, 43 out of 44 Chukchi and 21 out of 23 Naukan participants still possess specific knowledge of the process, for example: how to find nests, proper techniques and etiquette for gathering, storage, preparation, or botanical identity of species found. This reflects the rapid cultural changes that occurred during the Soviet period, including collectivization and consolidation of the population into larger villages. The maintenance of knowledge about resources that no longer play a large role in subsistence never-the-less aids in the resilience of local people to potential economic hardship and food insecurity. This particular relationship between humans, rodents, and plants provides an opportunity to examine the strengths and limitations for applying the concept of perspectivism in this cultural setting. These Chukotkan "mouse root" traditions show commonalities with similar practices among the neighboring Iñupiaq and Central Alaskan Yup'ik communities. Most notably, species gathered from rodent nests are similar on both sides of the Bering Strait as are rules for how to show proper respect to the animals when gathering. However, methods of preparation differ significantly between Chukotkan and Alaskan cultures.
\end{abstract}

Received June 18, 2019

OPEN ठACCESS

Accepted October 7, 2019

10.1.2019.1605

Published December 14, 2019

Keywords Ethnobotany, Traditional knowledge, Wild edibles, Chukotka, Chukchi, Naukan, Perspectivism

Copyright (C) 2019 by the author(s); licensee Society of Ethnobiology. This is an open-access article distributed under the terms of the Creative Commons Attribution-NonCommercial 4.0 International Public License (https://creativecommons.org/licenses/by-nc/4.0), which permits non-commercial use, distribution, and reproduction in any medium, provided the original author and source are credited.

\section{Introduction}

Arctic Ethnobotany and Changing Foodways

Although cross-cultural ethnobotanical studies in the arctic region are rare (Llano 1956; Yamin-Pasternak 2007), they have much potential. Flora of the circumpolar regions shows great similarities at the species and, especially, genus level (Walker et al. 1994). This provides an excellent opportunity to compare the role of these species in regions whose cultural, economic, and political conditions vary widely. Some pioneering studies have already begun this work. In an early example, Llano (1956) examined traditional uses of lichens along with their importance as a primary food source for reindeer herds of indigenous peoples of Scandinavia, Russia, and Alaska. Among other things, he discussed the management of these range lands under very different economic systems and styles of governance. More recently, Cuerrier et al. (2019) compared plant uses between the Canadian Iñuit villages of Nain and Kangiqsualujjuaq, finding only a $56 \%$ overlap in vascular species used, with more divergence in medicinal than edible species. The authors believe more research is needed to distinguish whether the differences are due more to knowledge erosion in recent times or to long-standing cultural divergence. Of particular note is Sveta Yamin-Pasternak's (2007) extensive research on ethnomycological attitudes and practices on the Seward Peninsula (Alaska) and in Eastern Chukotka (Russia). She found that Russian 


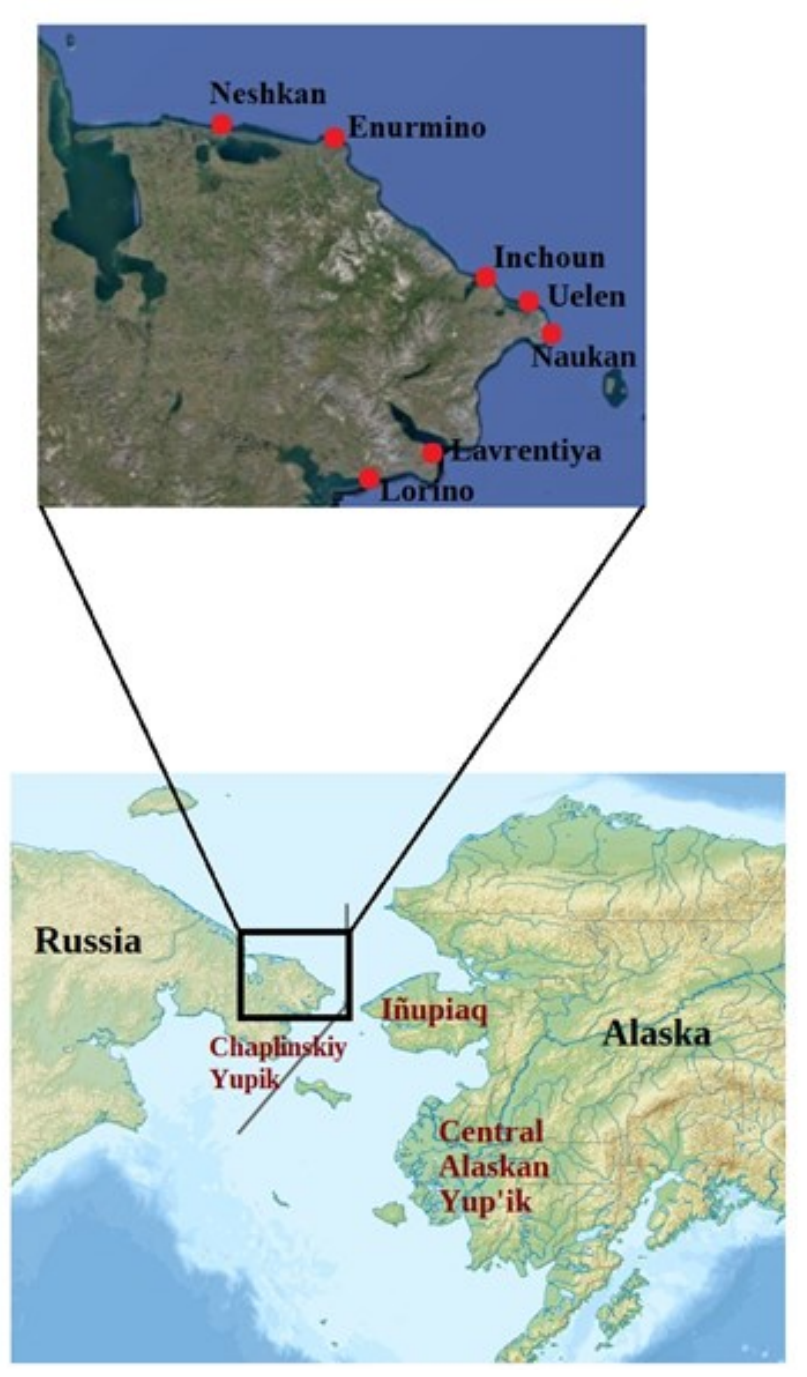

Figure 1 The study region and surrounding areas.

influence has had a profound effect on perceptions in Chukotka about the edibility and desirability of local mushroom species, while neighboring Alaskan cultures continue to consider many of the same species inedible and even dangerous.

In this same comparative spirit, the authors are currently completing a multi-year project (2014-2019) (NSF grant number 1304612) on edible and medicinal plant traditions among the Naukan and Chukchi of the Russian Far East and the Central Alaskan Yup'ik. The work examines whether there are more similarities in ethnobotanical traditions between two societies speaking closely related languages and sharing a deep historical root (Naukan and Central Alaskan Yup'ik), or between two societies speaking unrelated languages, but sharing the more recent influence of the dominant Russian culture (Naukan and Chukchi).

The current article focuses on one piece of the larger research, the tradition of gathering tubers, roots, and stem bases from rodent caches for human consumption. This subject is significant because: 1 ) it highlights the relationship between ethnobotanical knowledge and practice over a particularly economically and politically tumultuous period, and 2) it illustrates the ways in which a perspectivist world view (Viveiros de Castro 1998) has been both maintained and lost since the early writings of ethnographers such as Kjellman (1882) and Bogoraz (1904).

Gathering plant foods from rodent nests has been noted as a part of traditional subsistence among peoples of the arctic (Jones 2010), sub-arctic (Jernigan et al. 2015), and other regions (Nabhan 2009). Despite passing mentions, few articles have focused specifically on this practice. In one exception, Nabhan (2009) described how the Seri of Northern Mexico take legumes and cactus fruit from pack rat (Neotoma albigula) middens, allowing them to extend the availability of these plant foods beyond their typical season. Ståhlberg and Svanberg (2010) made an important historical analysis of gathering from the nests of vole and lemming species among peoples of Siberia and the Russian Far East. The authors argue that these practices were widespread in indigenous societies of those regions up to the eighteenth century, but appear to have been discontinued after the nineteenth century. However, brief references in the ethnobotanical literature (Ainana and Zagrebin 2014; Menovshchikov 1974) indicate that this tradition has survived longer in the Russian region of Chukotka. Here, we present the first detailed look at this subject among the Chukchi and Naukan peoples, along with a comparison of similar practices in neighboring societies (Ainana and Zagrebin 2014; Jernigan et al. 2015; Jones 2010).

\section{Ethnographic Setting}

We worked in the Chukotskiy district of Chukotka in the extreme northeast of Russia (Figure 1). The Naukan and most of the Chukchi population of this region reside in coastal villages, where subsistence activities center around hunting sea mammals, including the gray whale (Eschrichtius robustus), walrus 


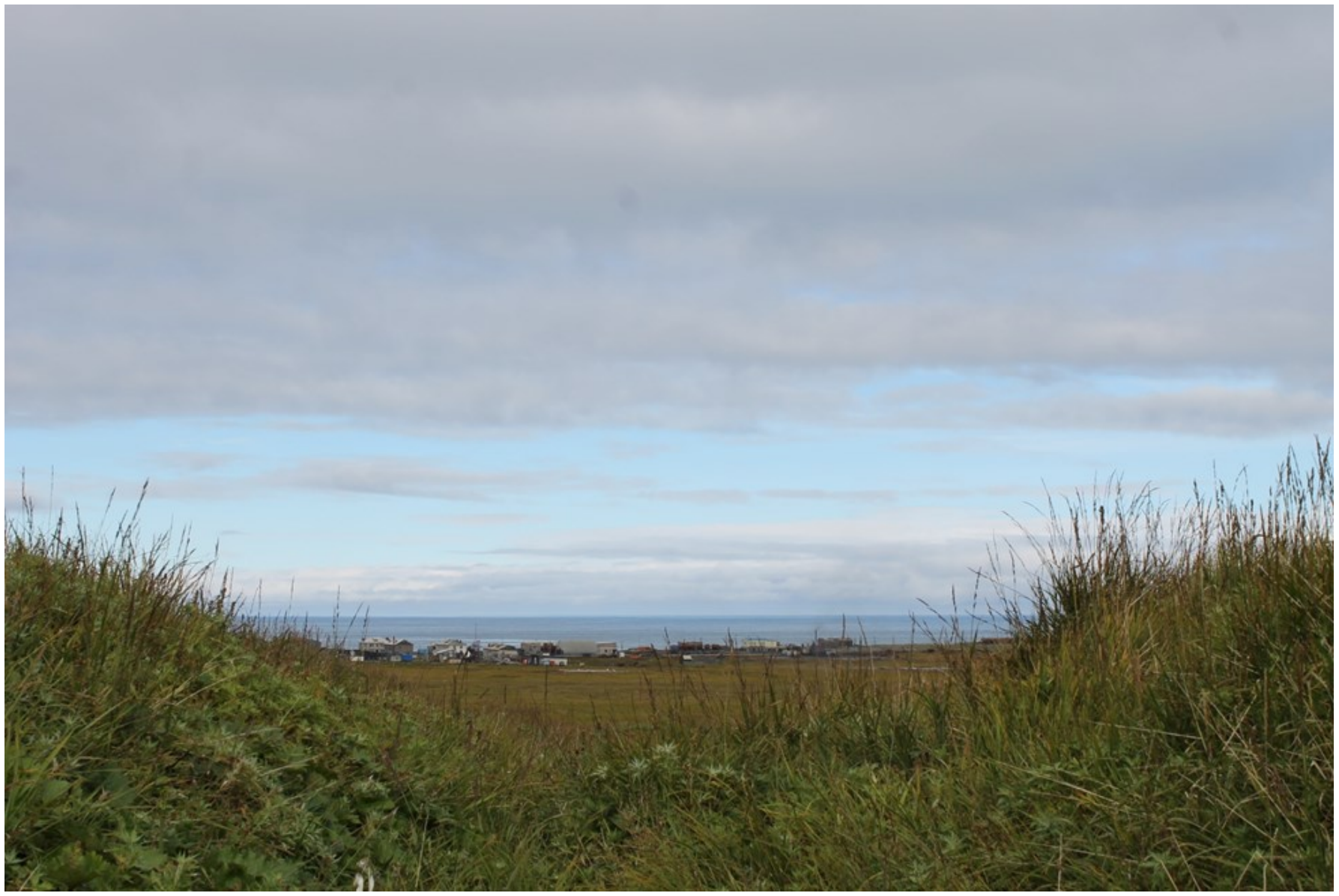

Figure 2 High-ground tundra where people search for "mouse roots," with the village of Neshkan in the background. Photo by Kevin Jernigan.

(Odobenus rosmarus), spotted seal (Phoca largha), and bearded seal (Erignathus barbatus). Fishing, hunting game, and gathering of wild plants also play an important role for both peoples (Jernigan et al. 2017). Ethnographers (Kerttula 2000; Kozlov et al. 2007) have typically drawn a cultural distinction between the coastal Chukchi and those who live in the interior as nomadic reindeer (Rangifer tarandus) herders. However, the coastal villages where we worked also show some influence from the interior traditions due to mixed marriages, as well as because some still have reindeer herding brigades left over from Soviet times (Krupnik and Chlenov 2013).

Russian contact began with seventeenth and eighteenth century explorers Semyon Dezhnev and Vitus Bering. The earliest ethnobotanical account came from Frans Reinhold Kjellman's (1882) work with the coastal Chukchi in 1878-1879. Bogoraz's (1904) more general Chukchi ethnography contains descriptions of subsistence and briefly mentions the gathering of tubers from rodent caches.

Russian political dominance in the study region solidified during the Soviet period. This brought collectivization of reindeer herders and sea mammal hunters into brigades, along with consolidation of the population into larger villages and the closure of smaller ones. This process particularly affected the Naukan people, who were concentrated, by this time, in a single village (also called Naukan or Nevuqaq). When that village was closed in 1958, everyone was forced to move to adjacent villages (Krupnik and Chlenov 2013). These processes accelerated acculturation, leading to changes in diet, spiritual practices, and language loss. The Chukchi language (Chukotko-Kamchatkan family) is currently considered "severely endangered," while Naukan (Iñuit-Yupik-Unangan family) is "critically endangered" (UNESCO 2010). These designations 
mean that the youngest generations are not learning the languages.

The Soviet period also saw an increased focus on ethnobotanical work here. For example, Sokolova (1961) and Mimykg Avtonova (1992) documented plant uses among the coastal Chukchi of Eastern Chukotka. However, relatively little work was done with the Naukan. Dobrieva et al. (2004) listed names for plants in their Naukan dictionary, while Mimykg Avtonova (1992) and Menovshchikov (1974) documented some uses of edible species.

Despite the negative aspects of Soviet rule for cultural survival, this era also brought a great deal of economic development and support from the central government, including support for the food supply. So, the breakup of the Soviet Union in 1991 caused considerable economic hardship in the following decades. The Survey of Living Conditions in the Arctic (Andersen et al. 2002) found widespread dissatisfaction in Chukotka with cost of living, job opportunities and availability of goods in local stores. This situation has led to a renewed reliance on local food sources, as well as innovations in how these local foods are stored, prepared, and consumed (Kozlov et al. 2007). Documenting the continuing importance of plants to these societies in the postSoviet context (Ainana and Zagrebin 2014; YaminPasternak 2007) is especially urgent.

\section{Methods}

The research took place from 2014-2016 in the villages of Lorino, Lavrentiya, Uelen, Inchoun, Enurmino, and Neshkan (Figures 1 and 2). Before starting the fieldwork, we obtained permission from the Institutional Review Board of the University of Alaska, and from local governmental authorities in Russia to carry out the work. The project conforms to
International Society of Ethnobiology ethical guidelines (2006), and prior informed consent was obtained from all study participants.

Our team began in each participating village by meeting with local people at community centers, museums, and hunting organizations to discuss the project goals, answer questions, and solicit suggestions or concerns related to the research activities. Study participants were recruited based on contacts made during these initial meetings, and then we used a referral sampling method (Cabanting and Perez 2016). We worked with 44 coastal Chukchi participants, ranging in age from 30 to 81 (mean $=58$ ). Since Naukan participants are from a single village and mostly older people still identify as Naukan, our sample of Naukan participants was smaller. We did not interview people who have one or more Naukan parents or grandparents, but did not identify with the Naukan culture. If more of those people did identify as Naukan, we would have potentially had a larger sample. We interviewed 23 Naukan people, ranging in age from 30 to 86 (mean = 65), including 63\% of all remaining full speakers of the Naukan language (Jernigan et al. 2017).

Research methods involved semi-structured interviews and participant observation of collection and use of local species. As part of our broader interviews, we asked people to freelist foods gathered from rodents' caches. We also asked how people locate the caches, along with details about the gathering process and how these foods are prepared. Voucher specimens collected for the wider project include the five "mouse root" species mentioned in this article. These are housed at the herbarium of the Komarov Botanical Institute in St. Petersburg, Russia, where they were identified with the help of botanist Vladimir Razzhivin.

Table 1 Plants ${ }^{1}$ identified as "Mouse Roots."

\begin{tabular}{|c|c|c|c|c|c|c|c|c|}
\hline Family & Genus & Species & Voucher \# & Chukchi name & $\begin{array}{l}\text { Chukchi } \\
\text { rank }\end{array}$ & Naukan name & $\begin{array}{l}\text { Naukan } \\
\text { rank }\end{array}$ & $\begin{array}{l}\text { Use by adjacent } \\
\text { cultures }\end{array}$ \\
\hline Crassulaceae & Rhodiola & integrifolia & KAJR18 & junew & - & saqlak & 4 & - \\
\hline Cyperaceae & Eriophorum & angustifolium & KAJR17 & pelqumret & 1 & pelkumraq & 2 & CAY \\
\hline Fabaceae & Hedysarum & hedysaroides & KAJR29 & mijmij & 2 & unataq & 1 & CAY, IN \\
\hline Montiaceae & Claytonia & acutifolia & KAJR45 & p'opoq & 4 & kegtaq & - & $\mathrm{CH}$ \\
\hline Polygonaceae & Persicaria & bistorta & KAJR12 & әр'et & 3 & neqenllaq & 3 & $\mathrm{CH}, \mathrm{IN}$ \\
\hline
\end{tabular}

${ }^{1}$ Species IDs conform to The Plant List (2013).

${ }^{2}$ CAY = Central Alaskan Yup'ik (Jernigan et al. 2015), IN = Iñupiat (Jones 2010), CH = Chaplinsky Yupik (Ainana and Zagrebin 2014). 


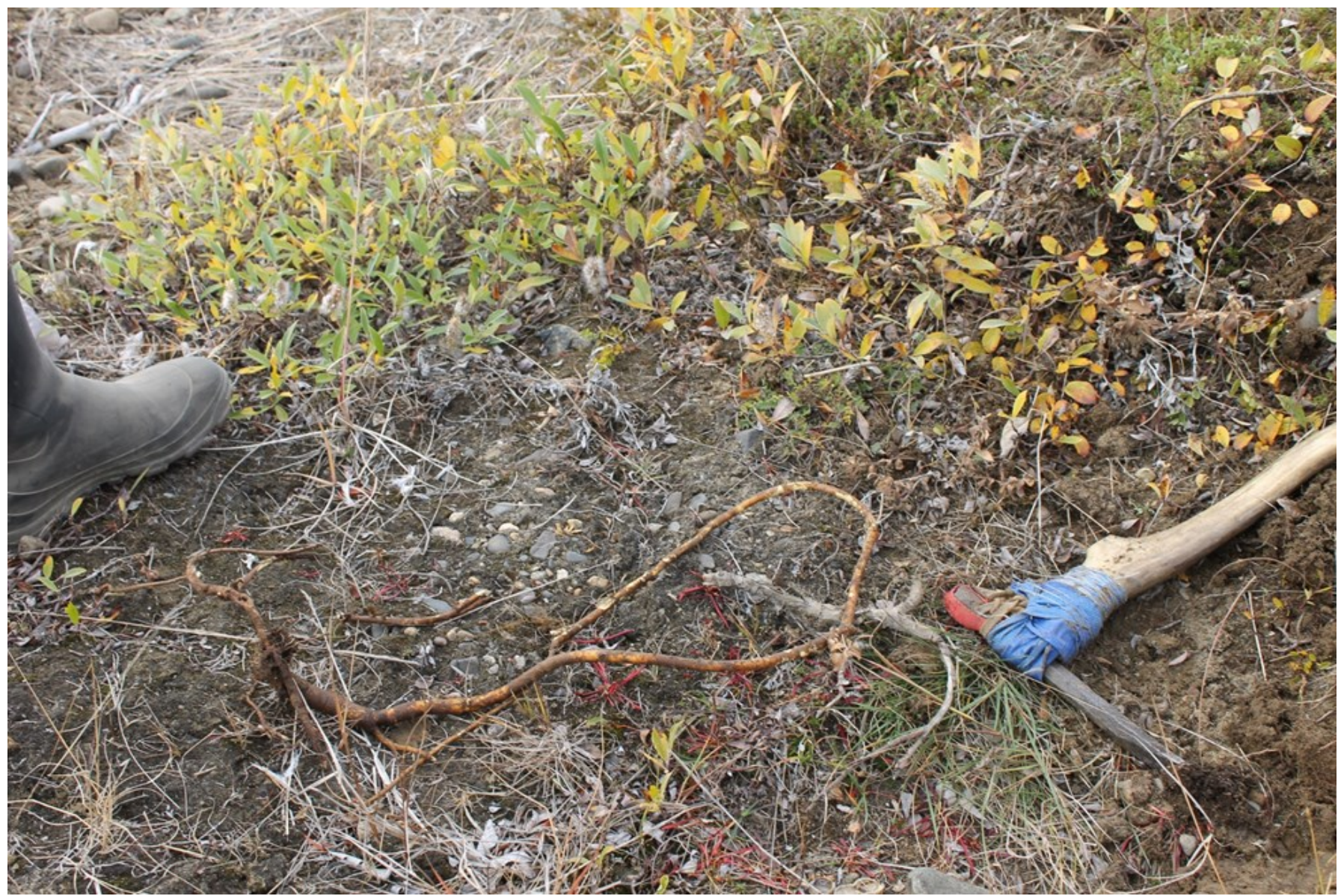

Figure 3 Digging for $H$. hedysaroides in Lorino. This species, reported as an important "mouse root," is now more commonly gathered by hand. Photo by Kevin Jernigan.

\section{Results and Discussion}

Table 1 shows the species that study participants said they gathered from rodents' nests and their relative importance for the two cultures. Collectively, these are known in local Russian as мышиные корешки (or little mouse roots). Although biologically imprecise, this term is particularly salient, since nearly everyone in the region is fluent in Russian, and the language plays an important role in cross-cultural communication. In Chukchi, the term pelqumret ${ }^{1}$ refers both to these foods in general and to tubers of Eriophorum angustifolium more specifically. Naukan participants gave peknet as a general term. The species gathered correspond fairly well between Naukan and Chukchi participants with the sedge E. angustifolium and legume Hedysarum hedysaroides (Figure 3) being the most important overall. All genera in our study, except Rhodiola, were also cited as gathered from rodent caches in ethnobotanical studies with at least one adjacent culture (Ainana and Zagrebin 2014; Jernigan et al. 2015; Jones 2010). Bogoraz (1904) reported that the Chukchi of his day gathered the tubers of Claytonia, Hedysarum, and Polygonum species, among others. He did not specify, however, which species were taken from rodent nests and which were gathered directly where they grew.

Ethnographic (Ståhlberg and Svanberg 2010) and biological (Batzli and Henttonen 1990; IUCN 2019) evidence suggest that the principal rodent species people gather from in this region is the root vole (Microtus oeconomus). Participants' descriptions of the nest layout, plant species stored, and summer gathering activities (Figure 4) are all consistent with that species. The arctic lemming (Dicrostonyx torquatus) and the lemming vole (Alticola lemminus) are other notable rodents present in this region. However, their diet and nesting habits (Batzli and Jung 1980; Chester 2016) do not correspond as well to the descriptions people gave. 


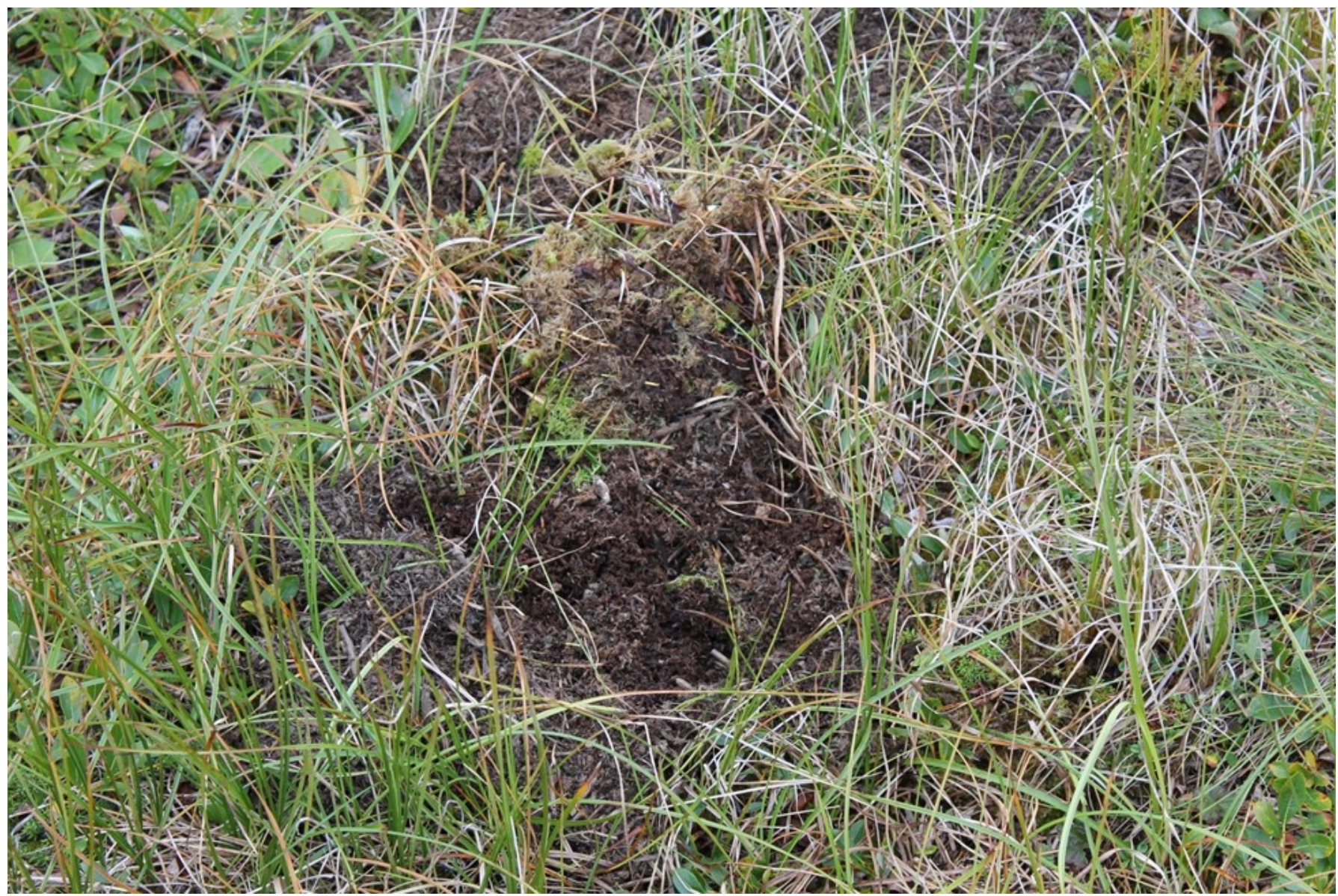

Figure 4 Summer foraging activity of the root vole. Photo by Kevin Jernigan.

We examined the academic literature to see whether the plant species mentioned in our interviews were also observed in biological field studies of $M$. oeconomus diet. While there appears to be no research in Chukotka, studies done in adjacent regions do help corroborate our ethnographic information. Most notably, biologists (Batzli and Henttonen 1990) working in arctic tundra at Toolik lake in Alaska reported finding tubers from E. angustifolium, a Hedysarum species, and Persicaria bistorta in root vole caches, giving independent support, at least for the species that study participants most commonly mentioned. Similarly, zoologists Nikiforov and Chibyev (2015) report finding Polygonum spp. and sedges in the genus Carex in root vole caches in the Central Sakha Republic.

Only eight out of 44 Chukchi respondents said that they still actively gather mouse roots, while none of the Naukan did. However, a much larger number from both groups remember the practice from their younger days. Forty-three out of 44 Chukchi and 21 out of 23 Naukan participants still possess specific knowledge of the process. For example, they described how to find nests, proper techniques and etiquette for gathering, storage, preparation, or the botanical identity of species found.

Many of the participants of both groups, who no longer gather mouse roots, described doing so when they were younger, with their parents or grandparents. People gave several kinds of reasons for not gathering now. First, some, who gathered as children, are no longer sure of their ability to find nests. Second, others simply do not consider mouse roots a necessary or preferred resource, stating that there is no need to gather wild tubers, when potatoes are available in stores. To further illustrate this point, when the potato became available from Russian traders, the Chukchi gave it the name kamçek, which also refers to the wild species Claytonia tuberosa. Third, some of these species, particularly $H$. hedysaroides, can also be harvested directly where they grow (Figure 3). 
Fourth, change in overall worldview also seems to be a factor, which will be discussed further below.

Gathering of mouse roots occurs in September or October, after the voles have completed their winter harvest, but before substantial snow cover. On rare occasions, when food was scarce, people would also try to harvest in the spring. Both men and women go out and search with their feet for hollow spots on the tundra. They use a digging-pick called a wigar in Chukchi and siklaq in Naukan (Dobrieva et al. 2004; see Figure 3 for a modern example) to peel back the tundra and access the subterranean caches. Participants described how rodents would often separate different roots in different chambers. Sometimes they would even find things in the nest that people find inedible.

Rules for proper harvesting of mouse roots are similar between Chukchi and Naukan participants and indeed, show many parallels with what has been reported (Jernigan et al. 2015) for neighboring Alaskan societies. Traditions governing proper gathering can be understood within the framework of perspectivism (Viveiros de Castro 1998), a world-view which posits that animals and people share the same cultural and social reality, while differing in their physical bodies. Although this concept was first developed in Amazonian ethnography (Århem 1993; Viveiros de Castro 1998), it has since been applied in other regions of the world, including the circumpolar north (Hill 2018; Willerslev 2004). There has recently been scholarly debate about the strengths and weaknesses of applying this concept to arctic and subarctic cultures. For example, Willerslev (2004) discussed the limitations of perspectivism in conceptualizing human-animal relationships among the Upper Kolyma Yukaghir, particularly for hunters identifying with their prey. Laugrand (2015) observed that one of the main complications in applying perspectivism to present-day Canadian Iñuit hunters is the degree to which their traditional worldview and spirituality have been influenced and transformed by Christianity.

Work on northern perspectivism has not focused much on plants. In one exception, Jernigan et al. (2015) noted that the Cup'ik of Chevak, Alaska draw an explicit parallel between each of the kinds of plant food they gather from vole nests and each type of seal that they hunt. They say that mice have their own seals in the form of the roots they collect. We now continue the discussion with our work in Chukotka.
When asked about proper gathering of mouse roots, Naukan and Chukchi participants most commonly cited the need to leave something in exchange for the rodents. The Chukchi preferred leaving bread, animal fat, or meat as a gift, while Naukans most often mentioned meat and tobacco. Although people stressed that this gift is purely symbolic and not meant to provide significant sustenance, the practice is never-the-less considered important. Some people said this is done to avoid offending the animals, while others compared it to buying something in a store. One person even left a coin.

People who continue the practice of reciprocity when gathering mouse roots still take perspectivist reasoning seriously. However, the reasoning given by people who do not gather mouse roots illustrates the weakening and replacement of this worldview by a more materialistic one. Some say, for example, that they are disgusted by this food, or feel sorry for the voles. This suggests a different kind of relationship, in which, rodents are not part of the same social reality as humans. Another example relates to Bogoraz's (1904) observation that the Chukchi of his day told him that voles have shamans and that these gather special roots that they employ just as humans used Amanita muscaria mushrooms. However, none of the people we interviewed said that mice have shamans. To be sure, people also said there are currently no human shamans in their villages.

The Central Alaskan Yup'ik (Jernigan et al. 2015) and the Iñupiat of the Kotzebue region (Jones 2010) follow similar rules when collecting mouse food. Elders from those regions reported that they do not take all the roots from the caches and leave a symbolic offering of food, such as dried fish. Ståhlberg and Svanberg (2010) also noted these two customs in their research on historical gathering of mouse roots in Siberia and the Russian Far East.

Chukchi participants most commonly eat mouse roots with sea mammal fat, especially rendered seal oil. One popular dish, particularly for E. angustifolium, is svitkeret, boiled walrus meat. Many also eat these foods with mulemul ('blood') or welmulemul ('aged blood') from seals or reindeer. Another dish of the tundra Chukchi is called qemeer'an, made by mixing greens, blood, and mouse roots such as E. angustifolium, and putting that in a reindeer stomach which can be frozen for later use. One elder fondly recalled the resulting stomach cut open with a filling 
dotted with mouse roots as being "like Snickers [candy bar]." Naukan respondents most commonly ate mouse roots with seal oil. People also boiled them in sea mammal fat when they lived in Naukan. In contrast, the neighboring Central Alaskan Yup'ik often eat mouse roots cooked in soup, or mixed with sugar and oil or animal fat in a dish called akutaq (Jernigan et al. 2015).

\section{Conclusion}

Although native foods are certainly still a marker of indigenous identity in Chukotka (Yamin-Pasternak 2014), just as they are among other arctic cultures (Cuerrier et al. 2019; Jones 2010), that does not mean these customs are static. Some, like the "mouse roots" we discuss here, appear to be declining, while others, such as mushrooms (Yamin-Pasternak 2007), have been added as a significant part of traditional subsistence.

However, current trends do not necessarily point to the inevitability of the disappearance of mouse root harvest. Although a fairly small number of Chukchi and none of the Naukan participants still gather these tubers, a large majority of both groups still remember details of the process passed from older generations. Indeed, researchers (Quave and Pieroni 2015; Turner and Turner 2008) have pointed out the significance of traditional ecological knowledge (TEK) that is preserved even in the face of discontinued practice, noting that such reservoirs of knowledge increase the resilience of local people to economic hardship and food insecurity. Indeed, many participants in our study spoke of a resurgence of plant harvesting in the tough years following the breakup of the Soviet Union.

The Chukotkan traditions we have documented here have significant parallels and some notable differences with those of neighboring Alaskan groups Jernigan et al. 2015; Jones 2010). There is a significant overlap in species gathered from rodents in both regions, while some differences may be due to the relative prevalence (CAVM Team 2003) of tundra types. Another notable similarity on both sides of the Bering Strait is in the protocol for gathering, particularly in giving a symbolic gift to the rodents in exchange for food taken. However, previous work (Jernigan et al. 2015) suggests that the tradition of gathering from rodent nests is more actively practiced in some parts of Alaska, especially among the Yup'ik of the lower Kuskokwim river and Bering sea region.
This particular relationship between humans, rodents, and plants also provides an opportunity to examine the advantages and limitations of applying the concept of perspectivism in this cultural setting. Although some study participants clearly still value a reciprocal relationship with the rodents, where food, tobacco, and even coins can be given in exchange for roots, others espouse a more materialistic view.

The authors are currently looking at this issue in greater detail among the Central Alaskan Yup'ik to expand the discussion of the plant traditions of the Bering Strait region. Future work could also explore this subject in other adjacent locations such as Little Diomede and the Seward Peninsula, which both had a high degree of historical contact with the Naukan and Chukchi.

\section{Notes}

${ }^{1}$ Here we use the simplified version of the International phonetic alphabet used in some scientific publications on the Chukchi language (e.g., Dunn 1999).

${ }^{2}$ We employ the Naukan orthography used the Naukan Yupik. Eskimo Dictionary (Dobrieva et al. 2004).

\section{Acknowledgments}

We especially wish to thank the study participants in the villages of Lavrentiya, Lorino, Uelen, Inchoun, Enurmino, and Neshkan, who participated in this research and generously shared their time and knowledge with us. We also thank Gennady Zelensky for helping with the logistics of work in Chukotka and Vladimir Razzhivin for assistance with identification of the botanical voucher specimens. Thanks also to the Beringia National Park and the Chukotkan Autonomous Region of Russia for allowing the work to take place. We are grateful for the comments of two anonymous reviewers who gave useful suggestions for improving the article.

\section{Declarations}

Permissions: Human subject approval was obtained from the University of Alaska, Fairbanks Institutional Review Board (IRB) (approval \#465620-1), prior to beginning work. Permission was obtained from the government of the Chukotka Autonomous Region and from the Beringia National Park.

Sources of funding: The research was funded by the National Science Foundation's Arctic Social Science program, grant number 1304612 . 
Conflicts of Interest: None declared.

\section{References Cited}

Ainana L. I., and I. Zagrebin. 2014. Edible Plants Used by Siberian Yupike Eskimos of Southeastern Chukotka Peninsula, Russia. National Park Service, Shared Beringian Heritage Program, Anchorage, AK.

Andersen, T., J. Kruse, and B. Poppel. 2002. Survey of Living Conditions in the Arctic: Inuit, Saami and the Indigenous Peoples of Chukotka (SLICA). Arctic 55:310-315. DOI:10.14430/arctic713.

Århem, K. 1993. Ecosofia Makuna. In La Selva Humanizada: Ecologia Alternativa en el Trópico Humedo Colombiano, edited by F. Correa, pp. 109-126. Instituto Colombiano de Antropologifa, Bogotá, Colombia.

Batzli, G. O., and H. Henttonen. 1990. Demography and Resource Use by Microtine Rodents Near Toolik Lake, Alaska, USA. Arctic and Alpine Research 22:51-64. DOI:10.2307/1551720.

Batzli, G. O., and H. J. G. Jung. 1980. Nutritional Ecology of Microtine Rodents: Resource Utilization Near Atkasook, Alaska. Arctic and Alpine Research 12:483-499. DOI:10.2307/1550496.

Bogoraz, W. G. 1904. The Chukchee. Memoirs of the American Museum of Natural History, vol. 11, part 1. E. J. Brill Ltd, New York.

Cabanting, R. M. F., and L. M. Perez. 2016. An Ethnobotanical Study of Traditional Rice Landraces (Oryza sativa L.) Used for Medical Treatment in Selected Local Communities of the Philippines. Journal of Ethnopharmacology 194:767-773. DOI:10.1016/j.jep.2016.10.02.

Chester, S. 2016. The Arctic Guide: Wildlife of the Far North, vol. 106. Princeton University Press, Princeton, NJ.

CAVM Team. 2003. Circumpolar Arctic Vegetation Map, Scale 1:7,500,000, Conservation of Arctic Flora and Fauna (CAFF) map no. 1. US Fish and Wildlife Service, Anchorage, AK.

Cuerrier, A., C. Clark, and C. H. Norton. 2019. Inuit Plant Use in the Eastern Subarctic: Comparative Ethnobotany in Kangiqsualujjuaq, Nunavik, and in Nain, Nunatsiavut. Botany 97:271-282. DOI:10.1139/cjb-2018-0195.
Dobrieva E. A., E. V. Golovko, S. A. Jacobson, and M. E. Krauss. 2004. Naukan Yupik Eskimo Dictionary. Alaska Native Language Center, Fairbanks, AK.

Dunn, M. J. 1999. A Grammar of Chukchi. Unpublished Doctoral Dissertation, Department of Linguistics, Australian National University, Canberra, Australia.

International Society of Ethnobiology. 2006. International Society of Ethnobiology Code of Ethics [web page]. Available at: http:// ethnobiology.net/code-of-ethics/. Accessed on June 13, 2019.

IUCN. 2019. The IUCN Red List of Threatened Species [web page]. Available at: https:// www.iucnredlist.org/. Accessed on May 22, 2019.

Hill, E. 2018. Humans, Birds and Burial Practices at Ipiutak, Alaska: Perspectivism in the Western Arctic. Environmental Archaeology 24:434-448. DOI:10.1080/14614103.2018.1460031.

Jernigan K. A., O. Alexie, S. Alexie, M. Stover, R. Meier, C. Parker, M. Pete, and M. Rasmussen, eds. 2015. Guide to the Ethnobotany of the YukonKuskokwim Region. Alaskan Native Language Center, Fairbanks, AK. Available at: https:// www.uaf.edu/anlc/resources/yk_ethnobotany/ YK_Ethnobotany.pdf. Accessed on June 15, 2019.

Jernigan, K. A., O. S. Belichenko, V. B. Kolosova, and D. J. Orr. 2017. Naukan Ethnobotany in PostSoviet Times: Lost Edibles and New Medicinals. Journal of Ethnobiology and Ethnomedicine 13:61. DOI:10.1186/s13002-017-0188-1.

Jones, A. 2010. Plants That We Eat: Nauriat Niginaqtant_From the Traditional Wisdom of the Iñpiat Elders of Northwest Alaska. University of Alaska Press, Fairbanks, AK.

Kerttula, A. M. 2000. Antler on the Sea: The Yup'ik and Chukchi of the Russian Far East. Cornell University Press, Ithaca, NY.

Kjellman, F. R. 1882. Om Tschuktschernas Hushållsväxter [On Chukchi Household Plants]. In Vega-expeditionens Vetenskapliga Iakttagelser, Bearbetade af Deltagare I Resan och Andra Forskare, vol. 1, edited by A .E. Nordenskiöld, pp. 353-372. F. \& G. Beijers, Stockholm, Sweden. 
Kozlov, A., V. Nuvano, and G. Vershubsky. 2007. Changes in Soviet and Post-Soviet Indigenous Diets in Chukotka. Etudes/Inuit/Studies 31:103-119. DOI:10.7202/019717ar.

Krupnik, I., and M. Chlenov. 2013. Yupik Transitions: Change and Survival at Bering Strait, 1900-1960. University of Alaska Press, Fairbanks, AK.

Laugrand, F. 2015. Ontology on Ice: The Inuit of the Central Canadian Arctic and their Animals. La lettre du Collège de France 9:74-75. DOI:10.4000/lettrecdf.2203.

Llano, G. A. 1956. Utilization of Lichens in the Arctic and Subarctic. Economic Botany 10:367-392. DOI:10.1007/BF02859767.

Menovshchikov, G. А. 1974. Аикие Растения в Рационе Коренных Жителей Чукотки [Wild Plants in the Diet of Indigenous inhabitants of Chukotka]. Soviet Ethnography 2:93-99.

Mimykg Avtonova, I. V. 1992. Edible Wild Plants in Our Foods (Chukchi, Eskimo). Russian Social Science Review 33:85-96. DOI:10.2753/RSS1061-14283 30685.

Nabhan, G. P. 2009. Ethnoecology: Bridging Disciplines, Cultures and Species. Journal of Ethnobiology 29:3-7. DOI:10.2993/0278-0771-29. 1.3 .

Nikiforov, N. I., and V. Y. Chibyev. 2015. K Экологии Полёвки-экономки (Microtus oeconomus Pallas, 1778) в Биогеоценозах Таежно-аласных Экосистем Центрацьной Якутии. [Ecology of the Tundra Vole (Microtus oeconomus Pallas, 1778) in Biogeocenosis of Taiga-and-Alas Ecosystems of Central Yakutia]. Bulletin of the Federal University in the name of M.K. Ammosova 12:19-23.

Quave, C. L., and A. Pieroni. 2015. A Reservoir of Ethnobotanical Knowledge Informs Resilient Food Security and Health Strategies in the Balkans. Nature Plants 1:14021. DOI:10.1038/nplants.2014.21.

Sokolova, T. G. 1961. On the Question of the Use of Wild Flora by the Population of Cape Dezhnov. Writings of the Chukotkan Local History Museum 2:9697.
Ståhlberg, S., and I. Svanberg. 2010. Gathering Food from Rodent Nests in Siberia. Journal of Ethnobiology 30:184-202. DOI:10.2993/0278-0771-30.2.184.

The Plant List. 2013. Version 1.1 Published on the Internet; http://www.theplantlist.org. Accessed on September 16, 2019.

Turner, N. J., and K. L. Turner. 2008. "Where our Women Used to Get the Food": Cumulative Effects and Loss of Ethnobotanical Knowledge and Practice; Case Study from Coastal British Columbia. Botany 86:103-115. DOI:10.1139/B07-020.

UNESCO. 2003. Language Vitality and Endangerment. Available at: http://www.unesco.org/new/ fileadmin/MULTIMEDIA/HQ/CLT/pdf/

Language_vitality_and_endangerment_EN.pdf.

Accessed on June 1, 2019.

Viveiros de Castro, E. V. 1998. Cosmological Deixis and Amerindian Perspectivism. Journal of the Royal Anthropological Institute 4:469-488. DOI:10.2307/ 3034157.

Walker, M. A., F. J. Daniëls, and E. van der Maarel. 1994. Circumpolar Arctic Vegetation: Introduction and Perspectives. Journal of Vegetation Science 5:757764.

Willerslev, R. 2004. Not Animal, not Not-animal: Hunting, Imitation and Empathetic Knowledge among the Siberian Yukaghirs. Journal of the Royal Anthropological Institute 10:629-652. DOI:10.1111/ j.1467-9655.2004.00205.x.

Yamin-Pasternak, S. 2007. How the Devils Went Deaf: Ethnomycology, Cuisine, and Perception of Landscape in the Russian North. Unpublished Doctoral Dissertation, Department of Anthropology, University of Alaska, Fairbanks.

Yamin-Pasternak, S., A. Kliskey, L. Alessa, I. Pasternak, P. Schweitzer, G. K. Beauchamp, M. L. Caldwell, L. Frink, C. Giordano, E. V. Golovko, and S. Ellix Katz. 2014. The Rotten Renaissance in the Bering Strait: Loving, Loathing, and Washing the Smell of Foods with a (Re)acquired Taste. Current Anthropology 55:619-646. DOI:10.1086/ 678305. 